\title{
Potassium Mobility Potential of Forest Soil In Kurdistan Region, Iraq, As Estimated By Quantity- Intensity (Q/I) Relationships
}

\author{
Ghafoor A. Mam-Rasul ${ }^{*}$ and Shuela M. Sheikh-Abdullah \\ Department of Natural Resources, College of Agricultural Engineering Sciences, University of Sulaimani, Kurdistan Region \\ of Iraq, (ghafwr.mamrasul, shuela.abdulla)@univsul.edu.iq
}

\begin{abstract}
This study aimed to assess potassium(K) 's potential mobility for some soils located in the Kurdistan Region of Iraq. Five soil samples were collected from a depth of $(0-30) \mathrm{cm}$. For each sample, $5 \mathrm{~g}$ of soil was equilibrated with $50 \mathrm{ml}$ of $0.01 \mathrm{M} \mathrm{CaCl}_{2}$, amended with different $\mathrm{K}$ concentrations, and incubated for $24 \mathrm{~h}$ at 298 Kelvin. The supernatant was filtered, and K, Ca, and Mg were determined. Potassium exchange equilibrium was calculated from quantity-intensity $(Q / I)$ isotherms. Mean $\mathbf{A R}_{\mathrm{e}}{ }^{\mathrm{K}}$ values for all studied soils ranged between $2.4 \times 10^{-3}$ to $3.6 \times 10^{-3}\left(\mathrm{~mol} \mathrm{~L}^{-1}\right) 1 / 2$, which reveals that $\mathrm{K}$ was preferentially held at inner potions. The amount of labile $K\left(K_{L}\right)$ ranged from 0.479 to $1.191 \mathrm{cmolc}^{-1}$ in studied soils. The highest value of $K_{L}$ was in Kanypanka while the lowest value was in Goizha. The potential buffering capacity $\left(\mathrm{PBC}^{\mathrm{K}}\right)$ was between 619.56 and $857.37 \mathrm{cmolc} \mathrm{kg}^{-1}\left(\mathrm{~mol} \mathrm{~L}^{-1}\right)^{-1 / 2}$. All studied soils were characterized by low percent $K$ saturation and a high ability to replenish $K$ concentration in the soil solution. Gapon selectivity coefficient was relatively high and ranged from 5.64 to $7.88 \mathrm{~L} \mathrm{~mol}^{-1}$. Higher values of $K_{L}$ indicate a greater $K$ release into the soil solution. Such a high affinity of $K$ to the solid soil phase was attributed to both the elevated organic matter content in these soils and their strong buffering capacities.
\end{abstract}

Keywords: Forest soils, Gapon selectivity coefficient, labile K, Potential buffering capacity, Potassium quantity-intensity isotherms.

Received: September 10 $0^{\text {th }}, 2020$ / Accepted: December $28^{\text {th }}, 2020$ / Online: January $2^{\text {nd }}, 2021$

\section{Introduction}

Potassium $(\mathrm{K})$ is an essential nutrient that affects most biochemical and physiological processes that influence plant growth and metabolism. It also contributes to the survival of plants exposed to various biotic and abiotic stresses. (Wang et al., 2013).

The availability of $\mathrm{K}$ in soil solution depends on the status between its forms in the soil. Pal et al.(1999) argue that more than $50 \%$ of the $\mathrm{K}$ applied to soils can be adsorbed onto colloidal surfaces depending on the amount and type of clay minerals. Similarly, Ogwada \& Sparks (1986) and Metha \& Singh (1986) showed that $\mathrm{K}$ adsorption rate on mineralogy with illite and vermiculite adsorbing are much slower than montmorillonite and kaolinite.

Knowledge about the equilibrium between the quantity and intensity phases of $\mathrm{K}$ in the soil and the difference in $\mathrm{K}$ adsorption among soils is necessary to make precise $\mathrm{K}$ fertilizer recommendations (Sparks \& Huang, 1986). That due to the different adsorption behavior of $\mathrm{K}$ in soils affects the pathways of added $\mathrm{K}$ fertilizer and influences crop response. 
A typical Q/I curve is shown in figure 1. Various interpretations of parameters $\mathrm{AR}^{\mathrm{K}} \mathrm{e}, \Delta \mathrm{K}_{0}, \mathrm{PBC}^{\mathrm{K}}$, and $\mathrm{K}_{\mathrm{X}}$ have been made, which can be derived from a Q/I plot (LeRoux and Sumner, 1968). The slope of $\Delta \mathrm{Q} / \Delta \mathrm{I}$ measures the amount of labile $\mathrm{K}$ that can be removed before $\mathrm{ARe}^{\mathrm{K}}$ falls by more than a given amount that is a gradient of the linear part of the graph has generally been representing Potential BufferingCapacity $\left(\mathrm{PBC}^{\mathrm{K}}\right.$ ) of the soil (Lalitha and Dhakshinamoorthy, 2015).

The intercept of the curve with the activity ratio axis $(\Delta K=0)$ gives the value of $A R_{e}{ }^{K}$ in the soils. This expresses the availability or intensity of labile K in the soil. Schouwenburg \&Van Schuffelen(1963) theorized that if the $\mathrm{AR}_{\mathrm{e}}{ }^{\mathrm{K}}$ value is less than $0.001\left(\mathrm{~mol} \mathrm{~L}^{-1}\right)^{1 / 2}$, the adsorbed $\mathrm{K}$ will be at edge positions, and if it is more than $0.01\left(\mathrm{~mol} \mathrm{~L}^{-1}\right)^{1 / 2}$, the adsorbed $\mathrm{K}$ would be at planar positions, however, if the $\mathrm{ARe}^{\mathrm{K}}$ values ranged between 0.001 to $0.01\left(\mathrm{~mol} \mathrm{~L}^{-1}\right)^{1 / 2} \mathrm{~K}$ is preferentially held at inner potions.

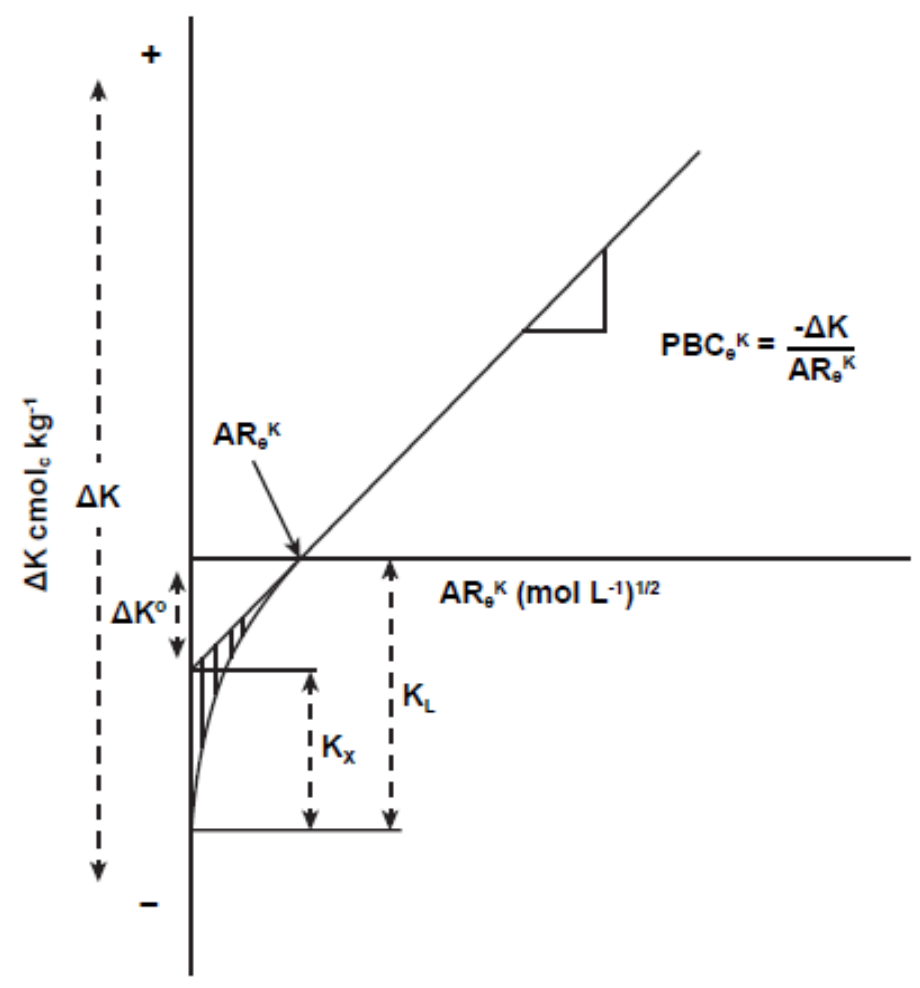

Figure 1.Typical quantity-intensity (Q/I) plot for labile soil K estimation

The lower bent portion of the curve (Figure 1) is an indicator of the exchange reactions of labile K retained at the position that demonstrates a higher affinity to K(i.e., ends of clay grains and wedge positions of weathered micas). Low values of $\mathrm{AR}_{\mathrm{e}} \mathrm{K}^{\mathrm{K}}$ characterize this portion because fixed $\mathrm{K}$ is releasing from the soil particle. The upper linear portion of the curve represents non-specific (planar surface) positions of K.

$\Delta \mathrm{K}^{\circ}$ is the measure of $\mathrm{K}$ adsorption on $\mathrm{p}$-positions (non-specific positions on outer crystal surfaces) which plant accessible. $\mathrm{K}_{\mathrm{x}}$ refers to the capability of the specific positions (potassium adsorption on e-positions; i.e., specific exchange positions taking place on the edges, bends, and projections of crystal surfaces) that are characterized by lower plant availability (Medvedeva, 1975). The value of $\Delta \mathrm{K}$ at $A R_{\mathrm{e}}{ }^{\mathrm{K}}=0$ refers to labile potassium $\left(\mathrm{K}_{\mathrm{L}}\right)$ in the adsorption curve. It indicates the overall amount of labile $\mathrm{K}$ in a given soil $\left(\Delta \mathrm{K}^{\circ}+\mathrm{K}_{\mathrm{x}}\right)$. Such an indicator reveals the readily available amount of $\mathrm{K}$, which can exchange during a period of equilibrium between the colloids and the soil solution.

The slope of $\Delta \mathrm{Q} / \Delta \mathrm{I}$ (i.e., $\mathrm{PBC}^{\mathrm{K}}$ ) is an index for the soil capacity to retain the high intensity of $\mathrm{K}$ in the soil solution. The $\mathrm{PBC}^{\mathrm{K}}$ deals with sorption-desorption mechanisms taking place in the soil. According to Zharikova (2004) can be $\mathrm{PBC}^{\mathrm{K}}$ grouped into five categories; very low (<20), low (20-50), medium (50- 
100), elevated (100-200), and high (>200 $\left.\mathrm{cmol}_{\mathrm{c}} \mathrm{kg}^{-1}\left[\mathrm{~mol} \mathrm{~L}^{-1}\right]^{-1 / 2}\right)$. Soils with the greatest $\mathrm{PBC}^{\mathrm{K}}$ values have the lowest $\mathrm{K}$ saturation rates, indicating a greater possibility of replenishing $\mathrm{K}$ intensity in the soil solution. The aims of this paper are; (i) evaluate K status in the forest soils from the Kurdistan Region of Iraq, (ii) study adsorption of $\mathrm{K}$ by using thermodynamic approaches, and (iii) evaluate $\mathrm{K}$ - supplying power for the forest soils using $\mathrm{Q} / \mathrm{I}$ parameters.

\section{Materials and methods}

\subsection{Study Site}

The study area is located in northeastern Iraq. Five forest areas were chosen, including Bakhy Bakhteyare

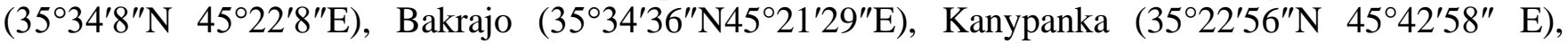

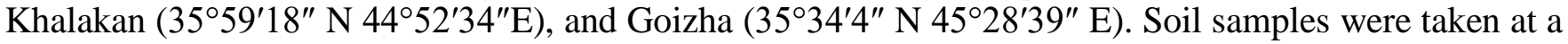
depth of 0 to $30 \mathrm{~cm}$. The samples were air-dried ground passed through a $2 \mathrm{~mm}$ sieve stored in plastic sample bags prior to laboratory analysis.

\subsection{Laboratory Analysis}

\subsection{Physico-chemical analysis}

The physicochemical analysis used in this study is shown in Table 1. Soil texture was determined by the standard pipette method (Day, 1965). The ICARDA (2013) method used to determine total calcium carbonate and active calcium carbonate was determined (Kozhekov \& Yakovleva, 1977). Soil organic matter was determined by the Walkley and Black method. Both the $\mathrm{pH}$ and electrical conductivity were determined in the soil saturation extract (Jackson, 1958). Soluble cations and anions were quantified in the soil extract solution; calcium and magnesium were determined titrimetically method using 0.01 Nethylenediaminetetra-acetic acid disodium salt (EDTA-Na2) as described in (Jackson, 1958). Potassium and sodium were measured by flame emission photometry following (Hesse, 1971). Carbonate and bicarbonate were determined by a titrimetric method using $0.01 \mathrm{~N} \mathrm{H}_{2} \mathrm{SO}_{4}$ and phenolphthalein and methyl orange as indicators (Richards, 1954). Chloride was determined by titration with $\mathrm{AgNO}_{3}$ and $\mathrm{K}_{2} \mathrm{CrO}_{4}$ as an indicator (Jackson, 1958).

\subsubsection{Thermodynamic approaches}

Ionic strength was calculated following (Griffin \&Jurinak, 1973) as:

$$
I=0.0129 \mathrm{EC}_{\mathrm{e}}
$$

Where $I$ is the ionic strength $\left(\mathrm{mol} \mathrm{L}^{-1}\right)$, and $\mathrm{EC}_{\mathrm{e}}$ represents electrical conductivity in $\mathrm{dS} \mathrm{m}{ }^{-1}$ at $25^{\circ} \mathrm{C}$.

The empirical Davies equation was used for calculating activity coefficients (Sposito, 1989)

$$
\log \gamma_{i}=-0.512 Z i^{2}\left[\frac{\sqrt{I}}{1+\sqrt{I}}-0.3 I\right]
$$

Where $\gamma_{i}$ is the mean activity coefficient of the electrolyte, $Z_{i}$ is the species valence of the ion, and $I$ is ionic strength in $\mathrm{mol} \mathrm{L}^{-1}$.

The activity ratio of potassium $\left(A R^{K}\right)$ was determined according to the ratio law (Beckett, 1964a).

$$
A R^{K}=\frac{a_{K}}{\sqrt{a_{C a}+a_{M g}}}
$$

Where $a$ represents the activity of ions in $\mathrm{mol} \mathrm{L}^{-1}$.

The free energy of $\mathrm{K}$ replenishment at equilibrium $\left(\Delta \mathrm{G}_{\mathrm{e}}{ }^{\mathrm{K}}\right)$, was determined using the following equation, as suggested by Kotur \& Rao (1988):

$$
\Delta G_{e}^{K}=-R T \ln A R^{K}
$$


Where $\Delta G_{e}{ }^{K}$ is the free energy of replenishment at equilibrium $\left(\mathrm{kJ} \mathrm{mol}^{-1}\right), A R^{K}$ is the $\mathrm{K}$ equilibrium activity ratio $\left(\mathrm{mol} \mathrm{L}^{-1}\right)^{1 / 2}$, and $R$ and $T$ are the gas constant and absolute temperature, respectively.

Gapon selectivity coefficient $\left(k_{G}\right)$ was used to understand K replacement capability in the soil. Here, $\mathrm{k}_{\mathrm{G}}$, as described by Beckett et al. (1966) and Sparks (1998), was calculated as follows:

$$
k_{G}=P B C^{K} / C E C
$$

where $\mathrm{k}_{\mathrm{G}}$ is units $\left(\mathrm{L} \mathrm{mol}^{-1}\right)^{1 / 2}, \mathrm{PBC}^{\mathrm{K}}$ is in units of $\mathrm{cmol}_{\mathrm{c}} \mathrm{kg}^{-1}\left(\mathrm{~mol} \mathrm{~L}^{-1}\right)^{-1 / 2}$, and $C E C$ is the cation exchange capacity $\left(\mathrm{cmol}_{\mathrm{c}} \mathrm{kg}^{-1}\right)$.

\subsubsection{Quantity/Intensity relationship}

$\mathrm{Q} / \mathrm{I}$ relationship of $\mathrm{K}$ for soil samples under study was assessed using the procedure described by Beckett (1964b). Five grams of each soil sample in duplicate were placed in $100 \mathrm{ml}$ plastic bottles and equilibrated with $50 \mathrm{ml}$ of $0.01 \mathrm{M} \mathrm{CaCl}_{2}$ at different concentrations of $\mathrm{K}, 0,5,10,25,50,100,200$, and $300 \mathrm{mg} \mathrm{L}^{-1}$, as $\mathrm{KCl}$ was added to the soils. The bottles were stoppered, shaken in a rotative shaker for three hours, and incubated for $24 \mathrm{~h}$ at 298 Kelvin to reach an equilibrium state. The supernatants were centrifuged and passed through filter paper Whatman No. 42, and the extract was kept to determine exchangeable calcium, magnesium, and potassium (Jackson, 1958) and measure electrical conductivity.

The quantity of $\mathrm{K}$ acquired or wasted $(\Delta \mathrm{K})$ by the soil was measured through the difference between the quantity of $\mathrm{K}$ added and the quantity recovered in the final solution.

The $Q / I$ parameters were obtained by plotting $\Delta K\left(\mathrm{cmol}_{\mathrm{c}} \mathrm{kg}^{-1}\right)$ against the activity ratio of potassium $\left(A R_{e}{ }^{K}\right)$ $\left.(\mathrm{mol} \mathrm{L})^{-1}\right)^{1 / 2}$. The variance between the lower and upper portions reveals the quantity of $\mathrm{K}$ held at particular sites $\left(K_{x}\right)$ when the activity ratio is zero. Moreover, extending the lower curved portion of the $\Delta K$ axis gives the overall quantity of $\mathrm{K}$ in the labile pool $\left(K_{L}\right)$. The $\mathrm{x}$-axis intercept is considered the equilibrium activity ratio $\left(A R_{e}{ }^{K}\right)$ in the soil when $\Delta K$ is zero. It gauges the availability or intensity of labile $\mathrm{K}$ in the soil.

The $\mathrm{y}$-axis intercepts for the lower portion of the curve represents the amount of $\mathrm{K}$ held in the soil at each site $(-\Delta K)$. Another $Q / I$ parameter is the potential buffering capacity of $\mathrm{K}$ at equilibrium $\left(P B C_{e}{ }^{K}\right)$, which is calculating as follows:

$$
P B C_{e}^{K}=\frac{-\Delta K^{o}}{A R_{e}^{K}}
$$

Where $P B C^{K}$ is the potential buffering capacity, $-\Delta K^{\circ}$ is the labile $K$ (quantity of $K$ desorbed or a portion of labile $\mathrm{K}$ situated on planar surfaces), and $\mathrm{AR}_{\mathrm{e}}{ }^{\mathrm{K}}$ is the equilibrium activity ratio for $\mathrm{K}$.

\section{Results and discussion}

\subsection{Soil properties}

Selected properties of the studied soils are presented in Table 1. The soil of all studied areas found as slightly alkaline with the $\mathrm{pH}$ ranged from 7.62 to 8.03 . $\mathrm{EC}_{\mathrm{e}}$ values ranged from 0.22 to $1.37 \mathrm{dS} \mathrm{m}^{-1}$ or nonsaline soils because the $\mathrm{EC}_{\mathrm{e}}$ values were found $<2.5 \mathrm{dS} \mathrm{m}^{-1}$, organic matter content ranged from 16.21 to $27.94 \mathrm{~g} \mathrm{~kg}^{-1}$. The total calcium carbonate equivalent and active calcium carbonate content were ranged from 42.80 to 272.60 and 15.00 to $135.00 \mathrm{~g} \mathrm{~kg}^{-1}$ respectively; the studied soils are calcareous. Cation exchange capacity (CEC) ranged from 37.50 to $46.68 \mathrm{cmol}_{\mathrm{c}} \mathrm{kg}^{-1}$, Table 2 . 
Table 1. Physical and chemical properties of studied soil samples

\begin{tabular}{|c|c|c|c|c|c|c|}
\hline \multirow{3}{*}{$\begin{array}{l}\text { Properties } \\
\text { Particle Size }\end{array}$} & \multicolumn{6}{|c|}{ Locations } \\
\hline & \multicolumn{2}{|c|}{ Bakhybakhtyare } & \multirow{2}{*}{$\begin{array}{c}\text { Bakrajo } \\
126.60\end{array}$} & \multirow{2}{*}{$\begin{array}{c}\text { Kanypanka } \\
80.20\end{array}$} & \multirow{2}{*}{$\begin{array}{c}\text { Khalakan } \\
260.60\end{array}$} & \multirow{2}{*}{$\begin{array}{c}\text { Goizha } \\
54.30\end{array}$} \\
\hline & Sand & 76.40 & & & & \\
\hline \multirow[t]{2}{*}{$\mathrm{g} \mathrm{kg}^{-1}$} & Silt & 333.20 & 407.90 & 422.20 & 304.10 & 507.10 \\
\hline & Clay & 590.40 & 465.50 & 497.60 & 435.30 & 438.60 \\
\hline Texture Class & & $\mathrm{C}$ & $\mathrm{SiC}$ & $\mathrm{SiC}$ & $\mathrm{C}$ & $\mathrm{SiC}$ \\
\hline $\mathrm{pH}$ & & 7.72 & 7.88 & 8.01 & 7.62 & 8.03 \\
\hline \multirow[t]{4}{*}{$\mathrm{EC}_{\mathrm{e},} \mathrm{dS} \mathrm{m}^{-1}$ at $25^{\circ} \mathrm{C}$} & & 0.26 & 0.56 & 0.88 & 1.37 & 0.22 \\
\hline & $\mathrm{Ca}^{2+}$ & 5.20 & 3.96 & 6.28 & 11.17 & 2.65 \\
\hline & $\mathrm{Mg}^{2+}$ & 3.00 & 1.86 & 3.04 & 7.76 & 1.75 \\
\hline & $\mathrm{K}^{+}$ & 0.35 & 0.40 & 0.70 & 0.13 & 0.63 \\
\hline Soluble ions & $\mathrm{Na}^{+}$ & 0.15 & 0.90 & 0.16 & 0.28 & 0.11 \\
\hline \multirow[t]{4}{*}{$\mathrm{mmol} \mathrm{L}-1$} & $\mathrm{HCO}_{3}^{-}$ & 3.60 & 3.15 & 3.90 & 12.00 & 2.60 \\
\hline & $\mathrm{CO}_{3}^{2-}$ & Nil & Nil & Nil & Nil & Nil \\
\hline & $\mathrm{Cl}^{-}$ & 1.20 & 0.70 & 0.50 & 2.65 & 1.10 \\
\hline & $\mathrm{SO}_{4}{ }^{2-}$ & 4.50 & 2.60 & 5.30 & 6.90 & 1.70 \\
\hline $\mathrm{O} \mathrm{M}, \mathrm{g} \mathrm{kg}^{-1}$ & & 23.98 & 21.73 & 27.94 & 19.32 & 16.21 \\
\hline $\mathrm{CaCO}_{3}$ equivalent & Total & 222.25 & 272.6 & 207.10 & 251.20 & 42.80 \\
\hline $\mathrm{g} \mathrm{kg}^{-1}$ & Active & 135.00 & 130.00 & 80.00 & 60.00 & 15.00 \\
\hline
\end{tabular}

Table 2. Quantity/Intensity parameter for studied soils

\begin{tabular}{|c|c|c|c|c|}
\hline Locations & $\mathbf{L}_{K}$ cmolc $_{\mathbf{c}} \mathbf{k g}^{-1}$ & $\begin{array}{c}\text { PBC }^{\mathrm{K}} \\
\text { cmol }_{\mathrm{ck}} \mathbf{k g}^{-1}\left(\mathrm{~mol} \mathrm{~L}^{-1}\right)^{-1 / 2}\end{array}$ & CEC cmol $_{\mathrm{c}} \mathrm{kg}^{-1}$ & $\begin{array}{c}\mathrm{k}_{\mathrm{G}} \\
\left(\mathrm{L} \mathrm{mol}^{-1}\right)^{1 / 2}\end{array}$ \\
\hline Bakhybakhtyare & 1.002 & 635.47 & 46.68 & 19.45 \\
\hline Bakrajo & 1.063 & 774.93 & 39.30 & 16.85 \\
\hline Kanypanka & 1.191 & 682.38 & 41.22 & 15.16 \\
\hline Khalakan & 0.804 & 619.56 & 37.50 & 18.66 \\
\hline Goizha & 0.479 & 857.37 & 37.70 & 22.78 \\
\hline
\end{tabular}

\subsection{Equilibrium activity ratio of $\mathrm{K}(\mathrm{AReK})$}

$A R_{e}{ }^{K}$ means value for all studied soils ranged between 0.0024 to $0.0036\left(\mathrm{~mol} \mathrm{~L}^{-1}\right)^{1 / 2}$ as shown inTable 3 . The results of this study support the idea that $A R_{e}{ }^{K}$ serves as an indicator for the condition of the instantly available $\mathrm{K}$, and therefore regulates the exchange of $\mathrm{K}$ ions from the exchange complex to the solution phase (Beckett, 1964b). This result reveals that $\mathrm{K}$ was preferentially held at inner potions, according to Schouwenburg \& Van Schuffelen (1963) theory. These results disagree with the finding by Mam-Rasul (2008), who studied K adsorption for some calcareous soils in the Kurdistan Region of Iraq and found that the $\mathrm{K}$ adsorbed was held at planar positions because the values of $A R_{e}{ }^{K}$ in that study ranged from 0.011 to $0.073\left(\mathrm{~mol} \mathrm{~L}^{-1}\right)^{1 / 2}$ with the mean of $0.035\left(\mathrm{~mol} \mathrm{~L}^{-1}\right)^{1 / 2}$ or more than $(0.01)\left(\mathrm{mol} \mathrm{L}^{-1}\right)^{1 / 2}$. 
Table 3. Energies of exchange, $-\Delta \mathrm{G}_{\mathrm{e}}^{\mathrm{K}}\left(\mathrm{kJ} \mathrm{mol}^{-1}\right)$, for different amount of added potassium and corresponding equilibrium activity ratios, $\mathrm{AR}_{\mathrm{e}}{ }^{\mathrm{K}}$

\begin{tabular}{|c|c|c|c|c|c|c|c|c|c|c|}
\hline \multirow{2}{*}{ 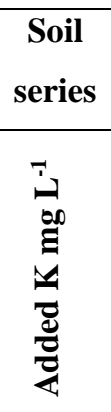 } & \multicolumn{2}{|c|}{ Bakhybakhtyare } & \multicolumn{2}{|c|}{ Bakrajo } & \multicolumn{2}{|c|}{ Kanypanka } & \multicolumn{2}{|c|}{ Khalakan } & \multicolumn{2}{|c|}{ Goizha } \\
\hline & 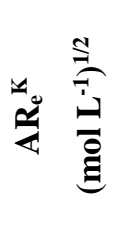 & 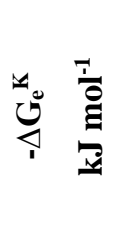 & 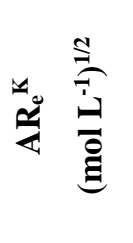 & 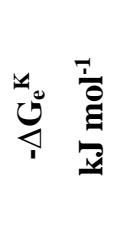 & 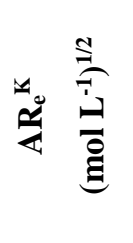 & 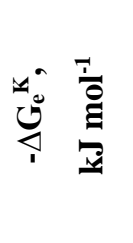 & 志 & 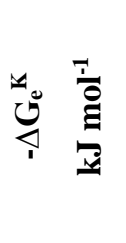 & 志 & 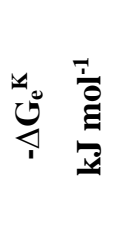 \\
\hline 0 & 0.0007 & -18.00 & 0.0007 & -18.00 & 0.0008 & -17.67 & 0.0004 & -19.38 & 0.0001 & -22.82 \\
\hline 5 & 0.0011 & -16.88 & 0.0008 & -17.67 & 0.0011 & -16.88 & 0.0008 & -17.67 & 0.0004 & -19.38 \\
\hline 10 & 0.0015 & -16.11 & 0.0012 & -16.66 & 0.0015 & -16.11 & 0.0011 & -16.88 & 0.0004 & -19.38 \\
\hline 25 & 0.0019 & -15.52 & 0.0019 & -15.52 & 0.0020 & -15.40 & 0.0019 & -15.52 & 0.0012 & -16.66 \\
\hline 50 & 0.0027 & -14.65 & 0.0027 & -14.65 & 0.0032 & -14.23 & 0.0026 & -14.75 & 0.0019 & -15.52 \\
\hline 100 & 0.0043 & -13.50 & 0.0041 & -13.62 & 0.0045 & -13.39 & 0.0044 & -13.44 & 0.0033 & -14.16 \\
\hline 200 & 0.0069 & -12.33 & 0.0068 & -12.37 & 0.0068 & -12.37 & 0.0071 & -12.26 & 0.0055 & -12.89 \\
\hline 300 & 0.0096 & -11.51 & 0.0071 & -12.26 & 0.0090 & -11.67 & 0.0088 & -11.73 & 0.0063 & -12.55 \\
\hline Mean & 0.0036 & -14.82 & 0.0032 & -15.09 & 0.0036 & -14.72 & 0.0034 & -15.20 & 0.0024 & -16.67 \\
\hline
\end{tabular}

\subsection{Labile $\mathrm{K}\left(\mathrm{L}_{\mathrm{K}}\right)$}

Labile $\mathrm{K}$ indicates the quantity of $\mathrm{K}$ capable of ion-exchange equilibrium conditions between soil solids and solution (Lalitha \& Dhakshinamoorthy,2015).

The data presented in Table 2 and Fig. 2 shows the total amount of $\mathrm{K}$ in the labile pool ranged between 0.479 and $1.191 \mathrm{cmol}_{\mathrm{c}} \mathrm{kg}^{-1}$ in studied soils; this variation may be due to the amount of $\mathrm{CaCO}_{3}$ equivalent in the soils. The higher levels of labile $\mathrm{K}\left(1.191 \mathrm{cmol}_{\mathrm{c}} \mathrm{kg}^{-1}\right)$ present in the soil at the Kanypanka location indicate that higher amounts of loosely bonded $\mathrm{K}^{+}$ions exist in exchangeable positions. Similar results were found by (Spark and Liebhardt, 1981; Diatta et al.,2006) as they reported that higher values of labile K indicated a large $\mathrm{K}$ release into soil solution resulting from a large pool of soil $\mathrm{K}$. The lower value of labile $\mathrm{K}\left(0.479 \mathrm{cmol}_{\mathrm{c}} \mathrm{kg}^{-1}\right)$ in the soil of Goizha location. This may be due to the high amount of 2:1 expanding clay minerals in surface soils at the Goizha location, which causes retention of K (Sheikh-Abdullah, 2012). A higher value of labile $\mathrm{K}$ is an indicator of a large $\mathrm{K}$ release into the soil solution (LeRoux, 1966). 



Figure 2. Quantity/Intensity plots for studied locations

\subsection{Potential buffering capacity $\left(\mathrm{PBC}^{\mathrm{K}}\right)$}

The potential buffering capacity $\left(\mathrm{PBC}^{\mathrm{K}}\right)$ is a measure of the amount of labile $\mathrm{K}$ that can be removed before $\mathrm{AR}_{\mathrm{e}}{ }^{\mathrm{K}}$ falls by more than given an amount; here, it is the slope of the linear portion of the $\mathrm{Q} / \operatorname{Icurve}(\Delta \mathrm{Q} / \Delta \mathrm{I})$ (Sparks, 1998; Rupa et al., 2003).

The data shown in Table 2 indicate that the value of $\mathrm{PBC}^{\mathrm{K}}$ for the studied soils ranged from 619.56 to $857.37 \mathrm{cmol}_{\mathrm{c}} \mathrm{kg}^{-1}\left(\mathrm{~mol} \mathrm{~L}^{-1}\right)^{-1 / 2}$. The values of $\mathrm{PBC}^{\mathrm{K}}$ for all studied soils were more than $200 \mathrm{cmol}_{\mathrm{c}} \mathrm{kg}^{-1}(\mathrm{~mol}$ $\left.\mathrm{L}^{-1}\right)^{-1 / 2}$, which indicates a high $\mathrm{K}$ buffering capacity for the studied soils, according to Zharikova (2004) categories. These results disagree with Mam-Rasul's (2008) results, who found medium $\mathrm{K}$ buffering in calcareous soils of the Kurdistan Region of Iraq because the values of $\mathrm{PBC}^{\mathrm{K}}$ in that study ranged between 52.31 and $92.42 \mathrm{cmol}_{\mathrm{c} \mathrm{kg}}{ }^{-1}\left(\mathrm{~mol} \mathrm{~L}^{-1}\right)^{-1 / 2}$.

\subsection{Gapon selectivity coefficient $\left(\mathrm{k}_{\mathrm{G}}\right)$}

The soils' relative affinity was also estimated using the Gapon selectivity coefficient for potassium, which reflects the relative affinity developed by the soil for $\mathrm{K}$ with the existence of $\mathrm{Ca}$ for both the solid phase and solution phase of the soil during equilibrium condition (Datta et al., 2006). The $\mathrm{k}_{\mathrm{G}}$ values fluctuated within the range of 15.16 to $22.78\left(\mathrm{~L} \mathrm{~mol}^{-1}\right)^{1 / 2}$, suggesting that the relative affinity for $\mathrm{K}$ was quite similar and high (Table 2). This means that all studied soils have exhibited quite similar performance for K. Such a high affinity of $\mathrm{K}$ to the solid soil phase was attributed to the high content of organic matter and the strong buffering capacities. These results align with Sharma et al.(2012) finding that soils with high values of $\mathrm{k}_{\mathrm{G}}$ indicate a high affinity for $\mathrm{K}$. 


\subsection{Free energy of potassium replenishment at equilibrium $\left(\Delta \mathbf{G e}^{\mathrm{K}}\right)$}

Table 3 includes the results of $-\Delta \mathrm{G}_{\mathrm{e}}{ }^{\mathrm{K}}$ for the studied soils; the highest value of $-\Delta \mathrm{G}_{\mathrm{e}}{ }^{\mathrm{K}}$ was -14.72 and the lowest value was $-16.67 \mathrm{~kJ} \mathrm{~mol}^{-1}$. That means the $\mathrm{K}$ supply for all soils relatively high (i.e., $\Delta \mathrm{G}_{\mathrm{e}}^{\mathrm{K}}$ less than $-0.6 \mathrm{~kJ} \mathrm{~mol}^{-1}$ ), according to the standard for $-\Delta \mathrm{G}_{\mathrm{e}}{ }^{\mathrm{K}}$ suggested by Woodruff (1955). These results are identical with Abaslou \& Abtahi (2008) findings who found similar results in their study on some soils of Iran.

\section{Conclusions and recommendations}

The present study describes the $\mathrm{K}$ mobility in five forest soil samples in the Kurdistan Region of Iraq. Potassium Q/I relation is utilized for forecasting $\mathrm{K}^{+}$availability for plants. Q/I approach offers valuable information to better understand $\mathrm{K}$ availability in calcareous soils and might be exploited in $\mathrm{K}$ fertilizer recommendations.

The Kurdistan Region soil is calcareous, and smectite is the predominant soil mineral, which has a high capacity for $\mathrm{K}$ fixation. In this study, $\mathrm{AR}_{\mathrm{e}}{ }^{\mathrm{K}}$ values indicate that $\mathrm{K}$ was preferentially held at inner positions, levels of labile $\mathrm{K}$ were generally high, and $\mathrm{K}$ buffering capacity was very high. The high affinity of $\mathrm{K}$ to the solid soil phase was attributed to both the high organic matter content and the strong buffering capacities of all the studied soils. Soils that have the greatest buffering capacity showed lesser K saturation rates, which consequently indicate the higher ability to replenish $\mathrm{K}$ concentrations in the soil solution. To sum up, thermodynamic approaches better estimation of plant available $\mathrm{K}$.

\section{References}

Abaslou, H. \& Abtahi, A. (2008). Potassium quantity-intensity parameters and its correlation with selected soil properties in some soils of Iran. Journal of Applied Sciences 8(10), 1875-1882.

Beckett, P.H.T. (1964a). Studies on soil potassium. I. confirmation of the ratio law: measurement of potassiumpotential. Journal Soil Science. 15(1), 1-8.

Beckett, P.H.T. ( 1964b). Studied on soil potassium. II. The immediate Q/I relations of labile potassium in the soil. Journal of Soil Science. 15(1), 9-23.

Beckett, P.H.T., Craig, J. B., Nafady, M.H.M., \& Watson, P. J.( 1966).Study on soil potassium. V. The stability of Q/I relations. Plant Soil, 25 (3), 435-455.

Day, P. R. (1965). Particle Fractionation and Particle-size Analysis. In Blacks, C. A. Methods of Soil AnalysisPart 1 Agronomy 9. American Society Agronomy Inc. Madison, WI. PP.545-567.

Diatta, C.W., Waclaw, Z., \& Grezebebisz, W. (2006). Evaluation of potassium quantity-intensity parameters of selected polish agricultural soils. Agronomy, 9(4), Available online http//www.eipau.media.pl.

Griffin, G.P., \& Jurinak,. J.J. ( 1973). Estimation of activity coefficient from the electrical conductivity of natural aquatic systems and soil extracts. Soil Science. 116 (1), $26-30$.

Hesse, P.R. (1971). A textbook of Soil Chemical Analysis.William Clowes and Sons Limited, London. International Center for Agricultural Research in the Dry Areas (ICARDA). (2013). Methods of Soil, Plant, and Water Analysis: A Manual for the West Asia and North Africa Region. 3rd ed. ICARDA, Beirut, Lebanon. p.68-73.

Jackson, M.L. (1958). Soil Chemical Analysis. Prentice-Hall. Inc., London.

Kotur, S.C., \& Rao, S.T. (1988). Quantity/intensity and quantity/potential studies in Na-Ca exchange system in some salt-affected soils. Journal of Soil Science. 39 (2), 199-207.

Kozhekov, D.K., \& Yakovleva, N.A. (1977). Determination of carbonates and carbonate minerals in soils. Soviet Soil Science, 9(5),620-626.

Lalitha, M. \& Dhakshinamoorthy, M. (2015). Quantity-intensity characteristics of Potassium (K) in relation to potassium availability under different cropping systems in alluvial soils. African Journal of Agricultural Research, 10(9), 2097-2103.

LeRoux, J. (1966). Studied on Ionic Equilibria in Natal Soils. Ph.D. dissertation University of Natal., Republic of South Africa.

LeRoux, J.\&Sumner, M.E. ( 1968). Labile potassium in soils: I. Factors affecting the quantity-intensity (Q/I) parameters. Soil Science, 106 (1), 35-41.

Mam-Rasul, Gh.A. (2008). Physico-chemical Behavior of potassium in Predominate Soil Orders of Sulaimani

Governorate. Ph.D. dissertation University of Sulaimani, Agriculture College, Soil and Water Science Department, Sulaimani, Kurdistan Region of Iraq.

Medvedeva, O.P. (1986). Agrochemical Methods of Soil Examination, Nauka, Moscow. p. 219-227. 1975.

Metha, S.C., \& Singh, M. (1986).Potassium adsorption kinetics in some soil samples. Journal of Indian Society of Soil Science, 34,484-487. 
Ogwada, R.A., \& Sparks, D.L. (1986).Use of mole or equivalent fraction in determining a thermodynamic parameter for potassium exchange in soils. Soil Science, 141 (4),268-273.

Pal, Y., Wong, M.T.F., \& Gilkes, R. I. (1999). The forms of potassium and potassium adsorption in some virgin soils from South-Western Australia. Australian Journal of Soil Research, 37 (4), 695-709.

Richards, L.A. (1954). Diagnosis and Improvement of Saline and Alkaline Soils. Agriculture Handbook No.60. USDA. Washington. DC.

Rupa, T.R., Srivastava, S., Swarup, A, Sahoo, D., \& Tembhare, B.R. (2003). The availability of potassium in Aeric Haplaquept and Typic Haplustert as affected by long-term cropping, fertilization, and manuring. Nutrient Cycling Agroecosystems, 65 (1), 1-11.

Schouwenburg, J.Ch., \& Van Schuffelen, A.C. (1963). Potassium exchanges behavior of an illite. Netherlands Journal of Agricultural Science, 11 (1), 13-22.

Sharma, V., Sharma, S., Arora, S., \& Kumar, A. (2012). Quantity-Intensity relationships of potassium in soils under some Guava Orchards on Marginal Lands. Soil Science and Plant Analysis, 43 (11), 1550-1562.

Sheikh-Abdullah, Sh. M. (2012). Effect of Plant Coverage on the Transformation of Mica to Expandable Minerals in Some Forest Soils of Kurdistan Region/Iraq. Ph.D. dissertation University of Sulaimani, Agriculture College, Soil and Water Science Department, Sulaimani, Kurdistan Region of Iraq.

Sparks, D.L. (1999). Kinetics of Sorption/Release Processes on Natural Surfaces. In P.M. Huang, N. Senesi, and

J. Buffle(ed.), Structure and Surface Reaction of Soil Particles. Vol. 4. John Wiley and Sons, New York, N Y.

Spark, D. L., \& Liebhardt, W.C. (1981). Effect of long-term lime and potassium application on quantity intensity relationships in sandy soil. Soil Science Society of America Journal, 45(20), 786-790.

Sparks, D.L., \& Huang, P.M. (1986). Physical Chemistry of Soil Potassium. In: R.D. Munson. editors, Potassium in Agriculture. SSA, Madison. WI. p.201-276.

Sposito, G. (1989). The chemistry of Soils. Oxford University Press, New York. NY.

Wang, M., Zheng, Q., Shen, Q., \& Guo, S. (2013). The critical role of potassium in plant stress response. International Journal of Molecular Sciences, 14(4), 7370-7390.

Woodruff, C.M. (1955). Energies of replacement of $\mathrm{Ca}$ and $\mathrm{K}$ in soils. Soil Science Society of America, Proceedings, 19 (2), 167-171.

Zharikova, E.A. (2004). Potential buffer capacity of soils with respect to potassium (by the example of the Amur River Region). European journal of soil science,37 (7),710-717. 